Original Article

\title{
Ionic homeostasis, biochemical components and yield of Italian zucchini under nitrogen forms and salt stress
}

\author{
Homeostase iônica, componentes bioquímicos e produção da abobrinha italiana sob \\ formas de nitrogênio e estresse salino
}

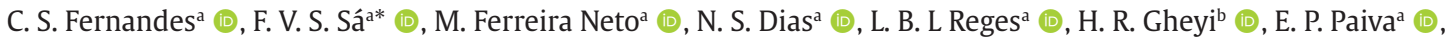 \\ A. A. Silva ${ }^{a}$ and A. S. Meloc (D) \\ aUniversidade Federal Rural do Semi-Árido - UFERSA, Centro de Ciências Agrárias, Mossoró, RN, Brasil \\ 'Universidade Federal do Recôncavo da Bahia- UFRB, Centro de Ciências Agrárias, Ambientais e Biológicas, Cruz da Almas, BA, Brasil \\ 'Universidade Estadual da Paraíba - UEPB, Departamento de Biologia, Campina Grande, PB, Brasil
}

\begin{abstract}
This research was carried out aiming at evaluating the effects of nitrate and ammonium ions on nutrient accumulation, biochemical components and yield of Italian zucchini ( $c v$. Caserta) grown in a hydroponic system under salt stress conditions. The experiment was carried out in a greenhouse utilizing an experimental design in randomized blocks, arranged in a $2 \times 5$ factorial scheme, with 4 replications. The treatments consisted of two forms of nitrogen (nitrate $-\mathrm{NO}_{3}{ }^{-}$and ammonium $-\mathrm{NH}_{4}^{+}$) and 5 electrical conductivity levels of irrigation water $\left(\mathrm{EC}_{\mathrm{w}}\right)\left(0.5,2.0,3.5,5.0\right.$ and $\left.6.5 \mathrm{dS} \mathrm{m} \mathrm{m}^{-1}\right)$. The analysis of the results indicated that supply of $\mathrm{N}$ exclusively in $\mathrm{NH}_{4}^{+}$ form promotes greater damage to the leaf membrane and reduction in accumulation of macronutrients and higher $\mathrm{Na}^{+} / \mathrm{K}^{+}, \mathrm{Na}^{+} / \mathrm{Ca}^{++}$and $\mathrm{Na}^{+} / \mathrm{Mg}^{++}$ratios in the shoots of zucchini plants. Electrical conductivity of irrigation water above $2.0 \mathrm{dS} \mathrm{m}^{-1}$ reduces the accumulation of nutrients in shoot and yield of Italian zucchini plant. The toxicity of $\mathrm{NH}_{4}^{+}$under Italian zucchini plants overlap the toxicity of the salinity, since its fertilization exclusively with this form of nitrogen inhibits its production, being the $\mathrm{NO}_{3}{ }^{-}$form the most suitable for the cultivation of the species.

Keywords: Cucurbita pepo L., electrolyte leakage, nitrogen fertilization, saline water.
\end{abstract}

\begin{abstract}
Resumo
Este trabalho foi desenvolvido com o objetivo de avaliar os efeitos dos íons nitrato e amônio sobre o acúmulo de nutrientes e produção da abobrinha italiana (cv. Caserta) cultivada em sistema hidropônico sob estrese salino. 0 experimento foi conduzido em casa de vegetação utilizando o delineamento experimental em blocos casualizados, arranjados em esquema fatorial $2 \times 5$, com 4 repetições. Os tratamentos foram constituídos de duas formas de nitrogênio (nitrato - $\mathrm{NO}_{3}{ }^{-}$e amônio $\left.-\mathrm{NH}_{4}{ }^{+}\right)$e cinco níveis de condutividade elétrica da água de irrigação $\left(\mathrm{CE}_{\mathrm{a}}\right)(0,5$; 2,$0 ; 3,5 ; 5,0$ e $6,5 \mathrm{dS} \mathrm{m}^{-1}$ ). As análises dos resultados indicaram que suprimento de $\mathrm{N}$ exclusivamente em forma de $\mathrm{NH}_{4}^{+}$promove maiores danos na membrana foliar e redução no acúmulo de macronutrientes e maiores relações $\mathrm{Na}^{+} / \mathrm{K}^{+}, \mathrm{Na}^{+} / \mathrm{Ca}^{++}$e $\mathrm{Na}^{+} / \mathrm{Mg}^{++}$na parte aérea das plantas de abobrinha. A irrigação com água a cima de $2,0 \mathrm{dS} \mathrm{m}^{-1}$ reduz o acúmulo de nutrientes na parte aérea das plantas e a produção de abobrinha. A toxicidade do $\mathrm{NH}_{4}^{+}$sob abobrinha italiana sobrepõe-se à toxicidade da salinidade, pois a fertilização exclusiva com esta forma de nitrogênio inibe sua produção, sendo a forma $\mathrm{NO}_{3}^{-}$a mais adequada para o cultivo da espécie.
\end{abstract}

Palavras-chave: Cucurbita pepo L., extravasamento de eletrólitos, adubação nitrogenada, água salina.

\section{Introduction}

Nitrogen is a limiting factor for crop growth and yield, since it is essential and required in large quantities by most plants (McAllister et al., 2012; Medeiros et al., 2016). Nitrogen nutrition in adequate quantities becomes essential for normal plant growth and satisfactory production. Under natural conditions, the two forms of nitrogen absorbed are the ions $\mathrm{NH}_{4}^{+}$and $\mathrm{NO}_{3}{ }^{-}$, with a variation in the preferential form of absorption of this nutrient among

the species (Helali et al., 2010). However, most species prefer to absorb it in the form of $\mathrm{NO}_{3}^{-}$, although there is a greater energy expenditure for its assimilation in this case (McAllister et al., 2012).

The higher energy expenditure of the plant to assimilate $\mathrm{NO}_{3}{ }^{-}$occurs because, unlike $\mathrm{NH}_{4}{ }^{+}$which is directly incorporated into amino acids by the enzymes glutamine synthase (GS) and glutamate synthase (GOGAT) 
(Bittsánszky et al., 2015; Silva Júnior et al., 2019), $\mathrm{NO}_{3}$ initially needs to be reduced to $\mathrm{NO}_{2}^{-}$by the nitrate reductase enzyme and then $\mathrm{NH}_{4}^{-}$by nitrite reductase enzyme, to then be incorporated by the enzymes GS and GOGAT (Bredemeier and Mundstock, 2000).

Besides playing an important role in improving growth and yield, nitrogen fertilization can mitigate the deleterious effects of salt stress on plants, including some studies point out that the availability of certain forms of nitrogen can interact with the physiological mechanisms of sensitivity and tolerance of plants to salt stress (Fernández-Crespo et al., 2012; Miranda et al., 2015). This interaction occurs because this macronutrient performs important functions in plant metabolism, such as structural functions and participation as a component of proteins, enzymes, RNA, DNA, ATP, chlorophyll, among other molecules (Chaves et al., 2011). In addition, it can promote the accumulation of organic compounds such as amino acids and soluble carbohydrates, which increase the osmotic adjustment capacity of plants, promoting acclimation to salinity and increasing their resistance to salt stress (Oliveira et al., 2010). However, this effect is strongly dependent on plant species and stress duration and intensity (Hessini et al., 2013).

Despite the possible benefits of an adequate nitrogen nutrition for the acclimation of plants to salt stress, the literature is divergent with respect to the action of forms of nitrogen as attenuator of the effects of salinity. Some authors argue that this occurs due to a favorable accumulation of nitrogen and/or a positive effect on ionic homeostasis (Miranda et al., 2015), while others advocate that this fact occurs due to the minimization of the effects of reactive oxygen species (Ashraf and Harris, 2004). However, it should be noted that, in general, $\mathrm{NH}_{4}{ }^{+}$tends to be toxic to plants (Britto and Kronzucker, 2002; Cruz et al., 2011; Bittsánszky, et al., 2015; Esteban et al., 2016).Thus, there is a need for investigations aimed at elucidating the possible benefits of nitrogen fertilization in the acclimation of plants to salt stress and how they occur.

Regarding the salinity tolerance of the vegetable species cultivated in Brazil, the Italian zucchini (Cucurbita pepo L.) is moderately sensitive to salt stress with threshold salinity (soil saturation extract) of $3.2 \mathrm{dS} \mathrm{m}^{-1}$ and yield losses of up to $9.4 \%$ per $\mathrm{dS} \mathrm{m}^{-1}$ (Dias et al., 2016). In relation to its national importance, Italian zucchini stands out among the vegetables for the great potential for commercialization and acceptance in the consumer market due to its food value and culinary versatility of its fruits (Azambuja et al., 2015).

Thus, based on the hypothesis that the form of nitrogen supply can constitute a management strategy for the acclimation of plants to salinity, this study aimed to evaluate the effects of $\mathrm{NH}_{4}^{+}$and $\mathrm{NO}_{3}$ - ions on the accumulation of nutrients, biochemical components and yield of Italian zucchini (cv. Caserta) cultivated in hydroponic system under salt conditions.

\section{Materials and Methods}

\subsection{Study location, treatments and statistical design}

The experiment was conducted from May to July 2018 in a greenhouse, located on the East Campus of the
Federal Rural University of the Semi-Arid Region (UFERSA), in the municipality of Mossoró/RN, Brazil ( $5^{\circ} 11^{\prime} \mathrm{S}$ and $37^{\circ} 20^{\prime} \mathrm{W}$, and $18 \mathrm{~m}$ altitude). The climate of the area where the experiment was conducted is classified as Equatorial Zone Tropical, with three subtypes (mild semiarid, medium semiarid and strong semiarid) (Diniz and Pereira, 2015). During the experimental period, the maximum and minimum temperatures were of 32.8 and $19.4^{\circ} \mathrm{C}$ and maximum and minimum relative air humidity of 86 and $33 \%$, while the daily mean values of temperature and relative air humidity throughout the experiment were $27.1^{\circ} \mathrm{C}$ and $65 \%$, respectively.

The experimental design adopted was randomized blocks, arranged in a $2 \times 5$ factorial scheme, with four replicates, totaling 40 experimental units, each of which contained 3 plants. The treatments consisted of two forms of nitrogen (nitrate - $\mathrm{NO}_{3}{ }^{-}$and ammonium - $\mathrm{NH}_{4}{ }^{+}$) and five levels of irrigation water electrical conductivity $\left(\mathrm{EC}_{\mathrm{w}}\right)(0.5$; 2.0; $3.5 ; 5.0$ and $6.5 \mathrm{dS} \mathrm{m}^{-1}$ ).

The nutrient solution was prepared based on the recommendation of Furlani et al. (1999), modified to contain nitrogen only in the form of $\mathrm{NO}_{3}^{-}$and only in the form of $\mathrm{NH}_{4}^{+}$. Nitrogen fertilizers $\mathrm{KNO}_{3}$ and $\mathrm{Ca}\left(\mathrm{NO}_{3}\right)_{2}$ were used to prepare the nitric nutrient solution, while for the ammoniacal nutrient solution, fertilizers $\left(\mathrm{NH}_{4}\right)_{2} \mathrm{SO}_{4}$, $\mathrm{NH}_{4} \mathrm{HPO}_{4}$, and $\mathrm{NH}_{4} \mathrm{Cl}$ were used.

\subsection{Experimental setup and analyses}

Italian zucchini (cv. Caserta) plants were cultivated in $8-\mathrm{dm}^{3}$ plastic pots, filled with coconut fiber substrate. At the bottom, the pots received a 2-cm-thick layer of crushed stone + geotextile to avoid substrate loss. The substrate was irrigated with public-supply water so as to substrate attain moisture content close to its maximum water retention capacity, and sowing was performed at $3 \mathrm{~cm}$ depth, by planting four seeds per pot. The pots were placed on bricks to avoid direct contact with the greenhouse floor, facilitating the drainage of the leachate.

At 10 days after sowing (DAS), when the seedlings were established, fertigation began to be applied with nutrient solution (Table 1 ). To avoid $\mathrm{NH}_{4}{ }^{+}$nitrification, a nitrification inhibitor (Dicyandiamide) was mixed in this solution at $10 \%$ of the $\mathrm{NH}_{4}^{+}-\mathrm{N}$ dose, thus guaranteeing the absorption of nitrogen exclusively in the ammoniacal form. The solutions were prepared using water from the supply system of the East Campus of UFERSA (Table 1), plus sodium chloride, calcium chloride and magnesium chloride salts in an equivalent proportion of 7:2:1 to achieve desired level of electrical conductivity.

From sowing to the $10^{\text {th }}$ day, plants were irrigated with supply water and then fertigated with the standard nutrient solution. Both irrigation and fertigation were performed twice a day (early morning and late afternoon), applying a water volume sufficient to replace the losses occurred by evapotranspiration. The water depth used was estimated by subtracting the leached water volume from the applied water volume (lysimetry). A drip irrigation system with pressure-compensating drippers with flow rate of $1.4 \mathrm{~L} \mathrm{~h}^{-1}$ was used. 
Table 1. Physico-chemical characterization of the supply water used to prepare the nutrient solutions and contents of nutrients used in its formulation.

\begin{tabular}{|c|c|c|c|c|c|c|c|c|c|}
\hline \multicolumn{10}{|c|}{ Physico-chemical characterization of the supply water ${ }^{1}$} \\
\hline \multirow{2}{*}{$\begin{array}{c}\mathrm{pH} \\
\mathrm{H}_{2} \mathrm{O}\end{array}$} & \multirow{2}{*}{$\frac{E C}{{\text { dS } \mathbf{m}^{-1}}}$} & $\mathbf{K}^{+}$ & $\mathrm{Na}^{+}$ & $\mathbf{M g}^{++}$ & $\mathrm{Ca}^{++}$ & $\mathrm{Cl}^{-}$ & $\mathrm{CO}_{3}^{--}$ & $\mathrm{HCO}_{3}^{-}$ & \multirow{2}{*}{$\begin{array}{c}\text { SAR } \\
\left(\mathrm{mmol} \mathrm{L}^{-1}\right)^{0.5}\end{array}$} \\
\hline & & \multicolumn{7}{|c|}{ 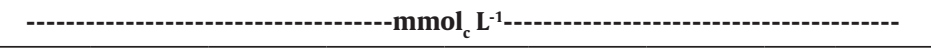 } & \\
\hline 7.57 & 0.54 & 0.31 & 3.79 & 1.20 & 0.83 & 2.40 & 0.60 & 3.20 & 3.73 \\
\hline \multicolumn{10}{|c|}{ Nutrients used in its formulation ${ }^{2}$} \\
\hline \multicolumn{2}{|c|}{ Stock Solution } & \multicolumn{3}{|c|}{ Concentration $\left(\mathrm{g} \mathrm{L}^{-1}\right)$} & & \multicolumn{2}{|l|}{$\mathrm{NO}_{3}^{-}$} & \multicolumn{2}{|c|}{$\mathrm{NH}_{4}^{+}$} \\
\hline \multicolumn{2}{|c|}{$\mathrm{KNO}_{3}-1 \mathrm{M}$} & \multicolumn{3}{|c|}{101.10} & & \multicolumn{2}{|l|}{$6 \mathrm{~mL} \mathrm{~L}^{-1}$} & \multicolumn{2}{|c|}{-} \\
\hline \multicolumn{2}{|c|}{$\mathrm{Ca}\left(\mathrm{NO}_{3}\right)_{2}-1 \mathrm{M}$} & \multicolumn{3}{|c|}{164.09} & & \multicolumn{2}{|l|}{$5 \mathrm{~mL} \mathrm{~L}^{-1}$} & \multicolumn{2}{|c|}{-} \\
\hline \multicolumn{2}{|c|}{$\mathrm{MgSO}_{4}-1 \mathrm{M}$} & \multicolumn{3}{|c|}{120.37} & & \multicolumn{2}{|l|}{$2.5 \mathrm{~mL} \mathrm{~L}^{-1}$} & \multicolumn{2}{|c|}{$2.5 \mathrm{~mL} \mathrm{~L}^{-1}$} \\
\hline \multicolumn{2}{|c|}{$\mathrm{KH}_{2} \mathrm{PO}_{4}-1 \mathrm{M}$} & \multicolumn{3}{|c|}{136.09} & & \multicolumn{2}{|l|}{$1.5 \mathrm{~mL} \mathrm{~L}^{-1}$} & \multicolumn{2}{|c|}{ - } \\
\hline \multicolumn{2}{|c|}{ Fe-EDTA ${ }^{3}$} & \multicolumn{3}{|c|}{-} & & \multicolumn{2}{|l|}{$1 \mathrm{~mL} \mathrm{~L}^{-1}$} & \multicolumn{2}{|c|}{$1 \mathrm{~mL} \mathrm{~L}^{-1}$} \\
\hline \multicolumn{2}{|c|}{ Micronutrients ${ }^{4}$} & \multicolumn{3}{|c|}{-} & & \multicolumn{2}{|l|}{$1 \mathrm{~mL} \mathrm{~L}^{-1}$} & \multicolumn{2}{|c|}{$1 \mathrm{~mL} \mathrm{~L}^{-1}$} \\
\hline \multicolumn{2}{|c|}{$\left(\mathrm{NH}_{4}\right)_{2} \mathrm{SO}_{4}-1 \mathrm{M}$} & & & & & - & & & $L^{-1}$ \\
\hline $\mathrm{NH}_{4}$ & $-1 \mathrm{M}$ & & & & & - & & & $\mathrm{LL} \mathrm{L}^{-1}$ \\
\hline & $1 \mathrm{M}$ & & & & & - & & & $\mathrm{L} \mathrm{L}^{-1}$ \\
\hline & & & & & & - & & & $\mathrm{L} \mathrm{L} \mathrm{L}^{-1}$ \\
\hline $\mathrm{K}_{2} \mathrm{~S}$ & $.5 \mathrm{M}$ & & & & & - & & & $L^{-1}$ \\
\hline & $1 \mathrm{M}$ & & & & & - & & & $\mathrm{L} \mathrm{L}^{-1}$ \\
\hline
\end{tabular}

${ }^{1} \mathrm{pH}$ - Hydrogen potential; EC - Electrical conductivity; $\mathrm{K}^{+}$- Potassium; $\mathrm{Na}^{+}$- Sodium; $\mathrm{Mg}^{2+}$ - Magnesium; $\mathrm{Ca}^{++}$- Calcium; $\mathrm{Cl}^{-}$- $\mathrm{Chloride}^{-\mathrm{CO}_{3}^{--}-}$ Carbonate; $\mathrm{HCO}_{3}^{-}$- Bicarbonate; SAR - Sodium adsorption ratio; ${ }^{2}$ Adapted from Furlani et al. (1999); ${ }^{3}$ (Disodium EDTA $\left.+\mathrm{FeSO}_{4} \cdot 7 \mathrm{H}_{2} \mathrm{O}\right) ;{ }^{4}\left(\mathrm{H}_{3} \mathrm{BO}_{3}+\right.$ $\left.\mathrm{MnSO}_{4}+\mathrm{ZnSO}_{4}+\mathrm{CuSO}_{4}+\mathrm{H}_{2} \mathrm{MO}_{4}\right)$.

\subsection{Mineral composition, biomass e fruiting production}

At the beginning of the flowering stage (30 DAS), plant samples were collected from each experimental plot to determine the mineral composition of the shoots, leaf pigments and leaf membrane damage. One plant of each experimental unit was cut close to the substrate surface to determine shoot dry biomass (SDB) and subsequently placed in paper bags and dried in a forced air circulation oven at $65^{\circ} \mathrm{C}$ until constant weight, to determine the dry weight on an electronic digital scale. Mineral composition analyses were performed by wet digestion, using the methodology described by EMBRAPA (2009) to determine the contents of phosphorus $(\mathrm{P})$, potassium $(\mathrm{K})$, $\operatorname{calcium}(\mathrm{Ca})$, magnesium $(\mathrm{Mg})$ and sodium $(\mathrm{Na})$ and the methodology cited by Tedesco et al. (1995), with some adaptations of EMBRAPA (2009), to determine the nitrogen content. These data were used to estimate the accumulated amount per plant and the relationship between the concentration of $\mathrm{Na}$ and the cationic elements $\mathrm{K}, \mathrm{Ca}$ and $\mathrm{Mg}\left(\mathrm{Na}^{+} / \mathrm{K}^{+}, \mathrm{Na}^{+} /\right.$ $\mathrm{Ca}^{++}$and $\mathrm{Na}^{+} / \mathrm{Mg}^{++}$).

The degree of membrane integrity was determied by electrolyte leakage (EE) according to the methodology described by Singh et al. (2007).

Leaf disks of $0.625 \mathrm{~cm}$ in diameter were removed from the same leaf used to determine the EE for the determination of the following chloroplastidic pigments: chlorophyll a (CLO a), chlorophyll b (CLO b) and carotenoids (CAROT). The pigments were extracted in a dimethyl sulfoxide solution saturated with $\mathrm{CaCO}_{3}$, following the methodology described by Wellburn (1994).

At 55 DAS, at the end of the experiment, the production per plant (PP) was quantified by weighing all fruits produced by the plants on a digital scale.

\subsection{Statistical analysis}

The data were analyzed using the statistical program SISVAR, version 5.6, obtaining the variances (ANOVA) and checking the significances at 0.05 and 0.01 probability levels using the $\mathrm{F}$ test. When there was significance, regression analysis was performed for $\mathrm{EC}_{\mathrm{w}}$ and means comparison test (Tukey test at 0.05 probability level) was carried out for the forms of nitrogen. When the interaction between factors was significant, the $\mathrm{EC}_{\mathrm{w}}$ factor was further analyzed at each form of nitrogen, by means of regression analysis.

\section{Results}

The interaction between the forms of nitrogen and water electrical conductivity was significant $(p<0.01)$ for zucchini production. The forms of nitrogen significantly influenced $(\mathrm{p}<0.01)$ all the studied variables of nutrient accumulation (N, P, K, Ca and $\mathrm{Mg}$ ), $\mathrm{Na}^{+} / \mathrm{K}^{+}, \mathrm{Na}^{+} / \mathrm{Ca}^{++}$and $\mathrm{Na}^{+} / \mathrm{Mg}^{++}$ratios, chlorophyll b, electrolyte leakage and SDB accumulation. In addition, there was significant effect of $\mathrm{EC}_{\mathrm{w}}$ on the accumulation of $\mathrm{N}, \mathrm{P}, \mathrm{K}, \mathrm{Mg}, \mathrm{Na}^{+} / \mathrm{K}^{+}, \mathrm{Na}^{+} / \mathrm{Mg}^{++}$ and shoot biomass accumulation $(\mathrm{p}<0.01)$ and on $\mathrm{Ca}^{++}$and 
$\mathrm{Na}^{+} / \mathrm{Ca}^{++}(\mathrm{p}<0.05)$. There was no effect $(\mathrm{p}>0.05)$ of forms of nitrogen and water electrical conductivity on chlorophyll a and carotenoids.

The plants fertilized with $\mathrm{NO}_{3}^{-}$had higher accumulation of macronutrients than those fertigated with nutrient solution containing $\mathrm{NH}_{4}^{+}$, with increments of $25.5 \%$, $54.0 \%, 61.4 \%, 165.3 \%$ and $215.9 \%$ for $\mathrm{N}, \mathrm{P}, \mathrm{K}, \mathrm{Ca}$ and $\mathrm{Mg}$, respectively (Figures $1 \mathrm{~A}-\mathrm{E}$ ).

In relation to the effects of irrigation water salinity, there were linear reductions in the accumulation of macronutrients in the tissue of zucchini plants with the increase of $\mathrm{EC}_{\mathrm{w}}$, which were equal to $32.8 \%, 40.8 \%$; $39.2 \%$, $36.8 \%$ and $37.6 \%$ for N, P, K, Ca and Mg, respectively, between the high and low salinity levels (Figures 2A-E).

$\mathrm{Na}$ accumulation in the shoots of Italian zucchini was $124.3 \%$ higher in plants fertilized with $\mathrm{NO}_{3}{ }^{-}$compared

A

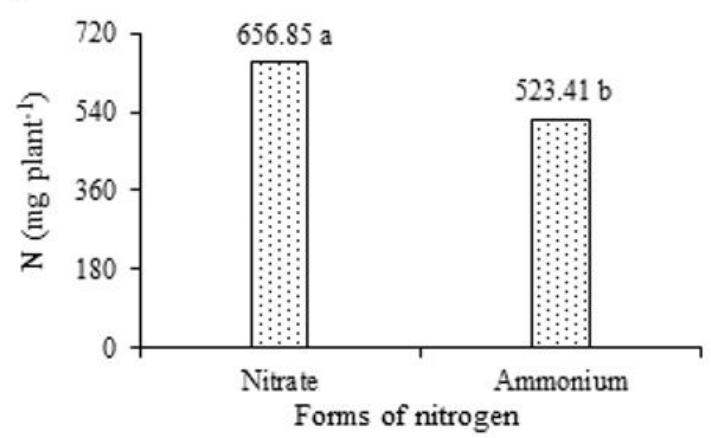

C

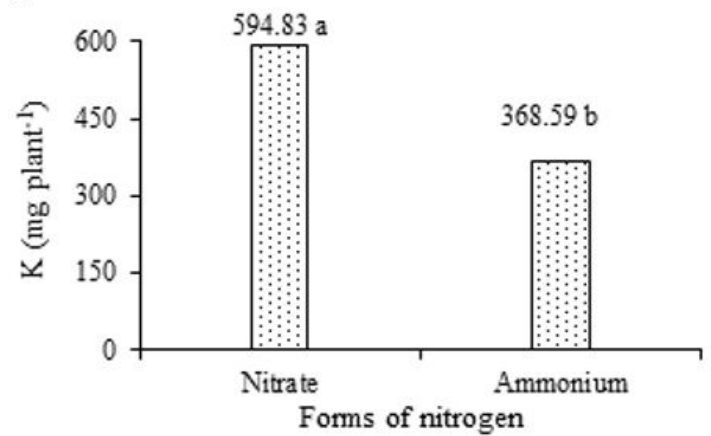

$\mathrm{E}$

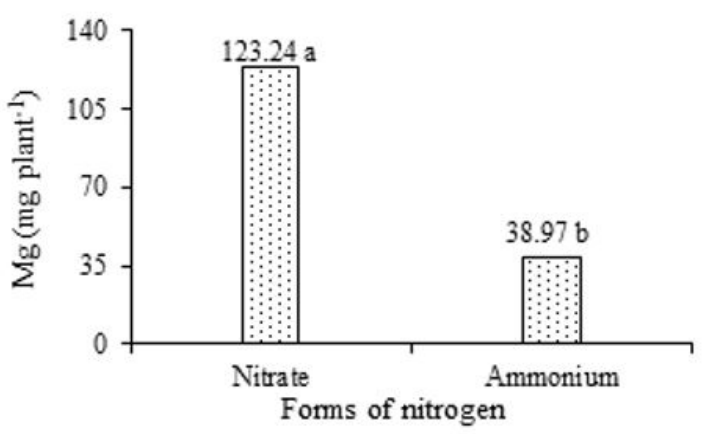

to plants nourished with $\mathrm{NH}_{4}^{+}$(Figure 3A). In addition, there were also higher values of $\mathrm{Na}^{+} / \mathrm{Ca}^{++}$and $\mathrm{Na}^{+} / \mathrm{Mg}^{++}$ ratios in plants fertilized with ammonium, with a $25.8 \%$ difference for $\mathrm{Na}^{+} / \mathrm{Ca}^{++}$and $54.6 \%$ difference for $\mathrm{Na}^{+} / \mathrm{Mg}^{++}$ (Figures $3 \mathrm{C}$ and $\mathrm{E}$ ). In relation to $\mathrm{Na}^{+} / \mathrm{K}^{+}, \mathrm{Na}^{+} / \mathrm{Ca}^{++}$and $\mathrm{Na}^{+} /$ $\mathrm{Mg}^{++}$as a function of the increment in irrigation water salinity, there were similar responses for these variables and their data fitted to the quadratic regression model, reaching the highest values $\left(0.30,0.39\right.$ and $1.91 \mathrm{for}^{+}{ }^{+}$ $\mathrm{K}^{+}, \mathrm{Na}^{+} / \mathrm{Ca}^{++}$and $\mathrm{Na}^{+} / \mathrm{Mg}^{++}$, respectively) at the $\mathrm{EC}_{\mathrm{w}}$ from $4.1 \mathrm{dS} \mathrm{m}^{-1}$ (Figures 3B, D and F).

The use of ammoniacal nitrogen increased the concentration of chlorophyll $b$ in the leaves of zucchini by $10.5 \%$ (Figure $4 \mathrm{~A}$ ). Regarding the state of membrane integrity, zucchini plants fertilized with $\mathrm{NH}_{4}^{+}$showed EE values more than two times higher than plants fertilized

B

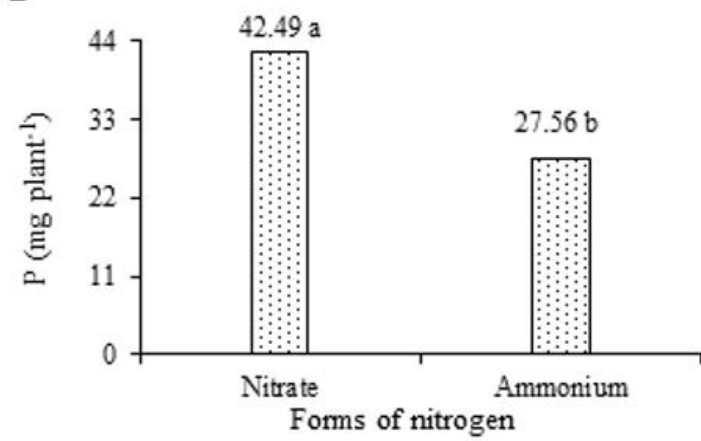

$\mathrm{D}$

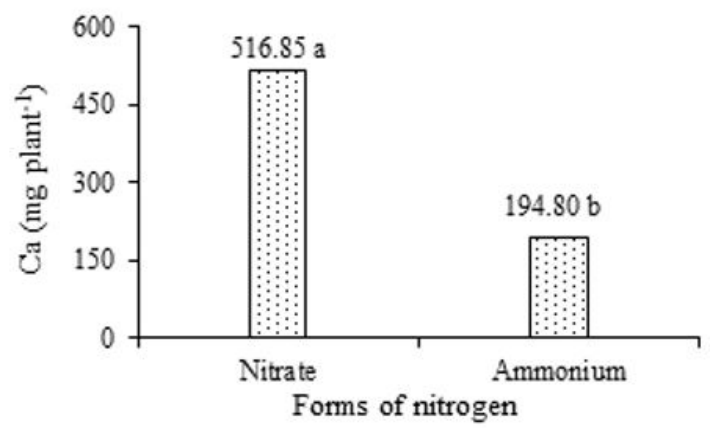

Figure 1. Accumulation of nitrogen - N (A), phosphorus - P (B), potassium - K (C), calcium - Ca (D) and magnesium - Mg (E) in Italian zucchini plants fertilized with different forms of nitrogen and irrigated with saline water. Means followed by different letters indicate significant difference by Tukey test at 0.05 probability level. 
A

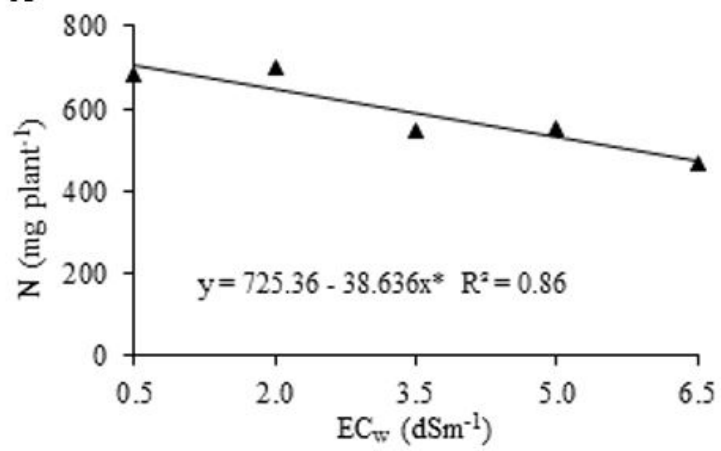

C

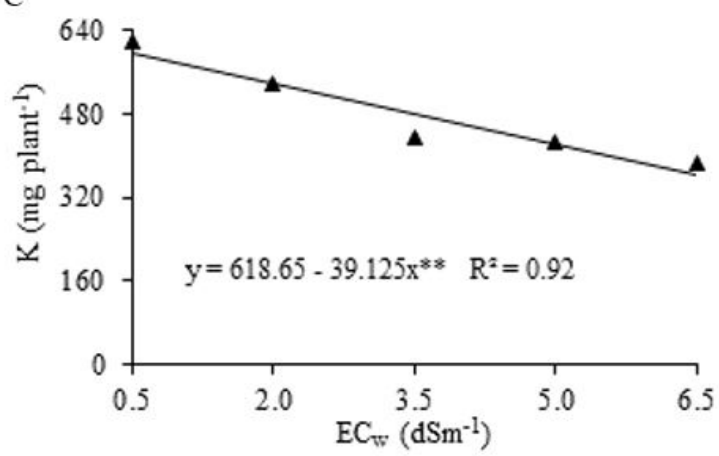

E

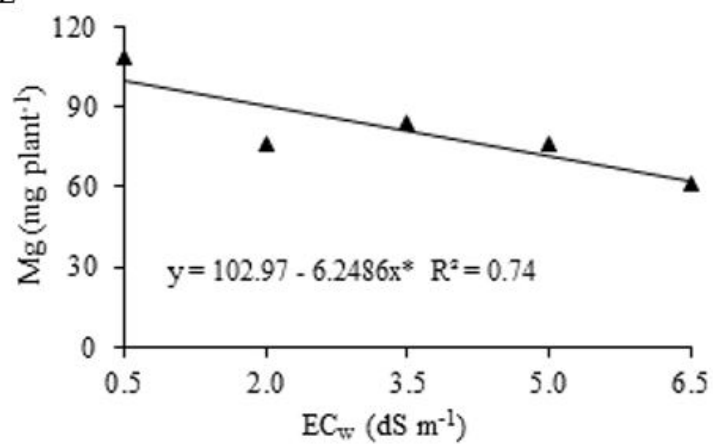

B

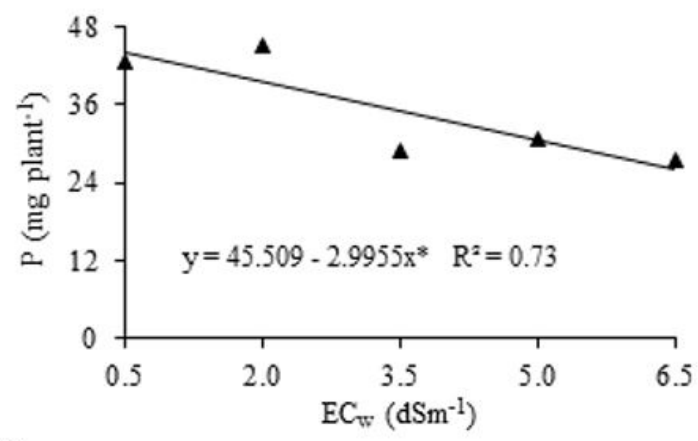

$\mathrm{D}$

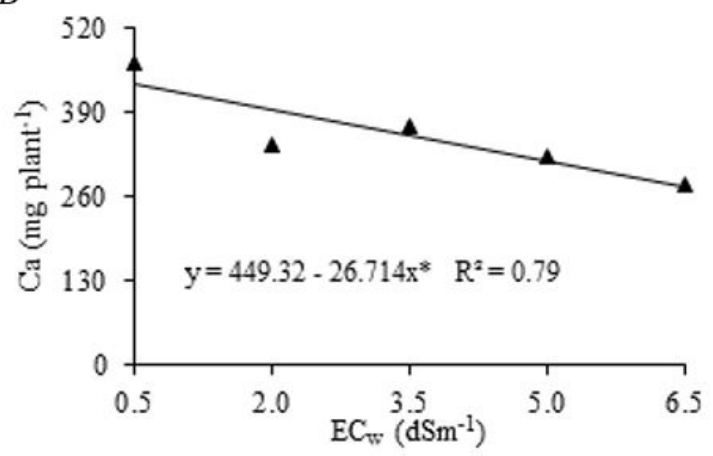

Figure 2. Accumulation of nitrogen $(\mathrm{N})(\mathrm{A})$, phosphorus $(\mathrm{P})(\mathrm{B})$, potassium $(\mathrm{K})(\mathrm{C})$, calcium $(\mathrm{Ca})(\mathrm{D})$ and magnesium $(\mathrm{Mg})(\mathrm{E})$ in Italian zucchini plants irrigated with saline waters. ${ }^{*}$ - Significant at 0.05 probability level $(\mathrm{p}<0.05)$.

with $\mathrm{NO}_{3}{ }^{-}$(Figure 4B). The mean values obtained in the presence of the two forms of nitrogen were 49.3 and $24.2 \%$ for $\mathrm{NH}_{4}^{+}$and $\mathrm{NO}_{3}^{-}$(Figure 4B).

Ammonium toxicity can be seen in Figure 5. Visually, in both forms of $\mathrm{N}$, the growth of plants is reduced by the increase in the electrical conductivity of irrigation water, with the greatest reductions in plants fertilized with $\mathrm{NH}_{4}^{+}$. Plants fertilized with $\mathrm{NO}_{3}^{-}$reduced growth due to the increase in saline levels of irrigation water, however, these plants managed to emit a good number of flowers at the highest level of salinity $\left(6.5 \mathrm{dS} \mathrm{m}^{-1}\right)$. On the other hand, plants fertilized with $\mathrm{NH}_{4}^{+}$showed reduced growth and marginal burns on the leaves in relation to plants fertilized with $\mathrm{NO}_{3}{ }^{-}$in all saline levels, with more evident reductions in salinity levels from $5.0 \mathrm{dS} \mathrm{m} \mathrm{m}^{-1}$, in which plants did not even managed to emit flowers.

Dry biomass accumulation was $62.8 \%$ higher in plants fertilized with $\mathrm{NO}_{3}{ }^{-}$in comparison to those nourished with
$\mathrm{NH}_{4}^{+}$(Figure 6A). In relation to salinity, shoot dry biomass was reduced by $31.4 \%$ as the salinity level increased from 0.5 to $6.5 \mathrm{dS} \mathrm{m}^{-1}$ (Figure 6B), corroborating with the results of nutrient accumulation. As for production, it was observed that only plant fertilized with $\mathrm{NO}_{3}{ }^{-}$reached the fruiting stage, while plants nourished with ammonium $\left(\mathrm{NH}_{4}^{+}\right)$did not produce and died within a few days after flowering, regardless of the salinity level (Figure 6C). Regarding the effects of salinity, there was a linear reduction in the production of plants nourished with $\mathrm{NO}_{3}{ }^{-}$, with a $91.8 \%$ reduction in the production per plant between the $\mathrm{EC}_{\mathrm{w}}$ levels of 0.5 and $6.5 \mathrm{dS} \mathrm{m}^{-1}$ (Figure 6C).

\section{Discussion}

Salt stress is caused by excess ions in the rhizosphere, limiting water extraction by the roots and reducing 
A

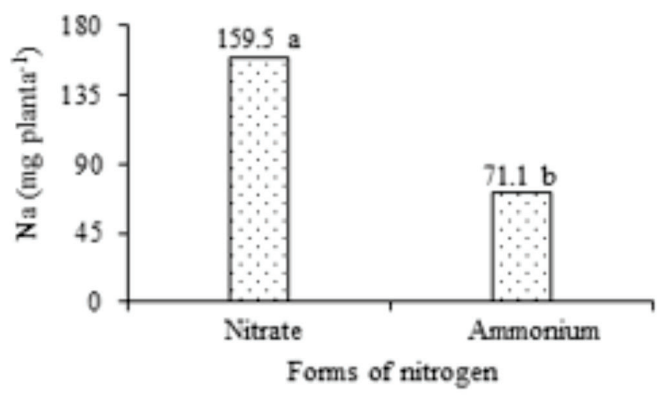

$\mathrm{C}$

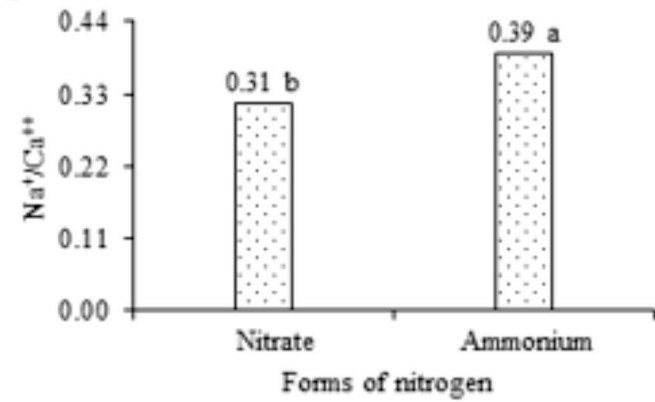

E

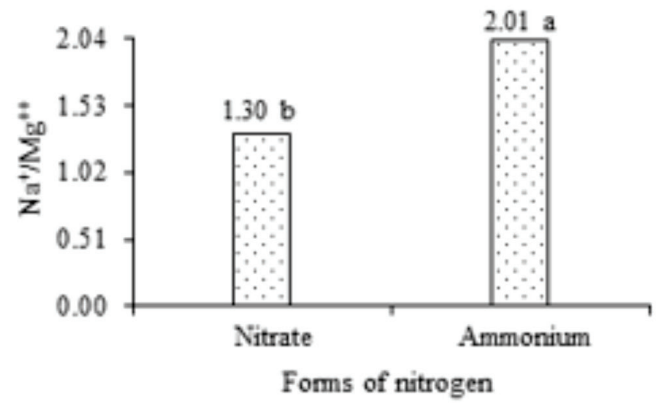

B

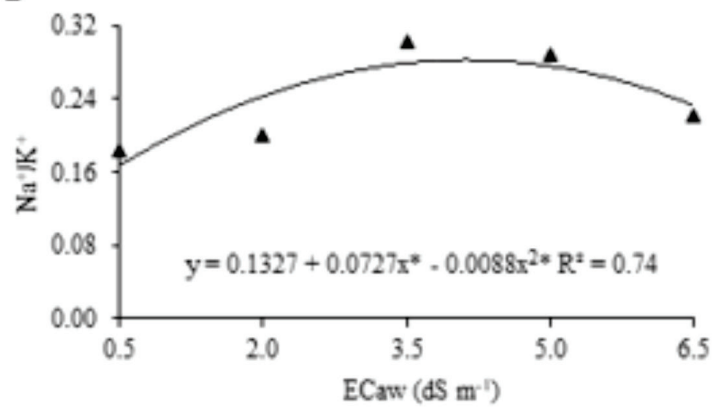

$\mathrm{D}$

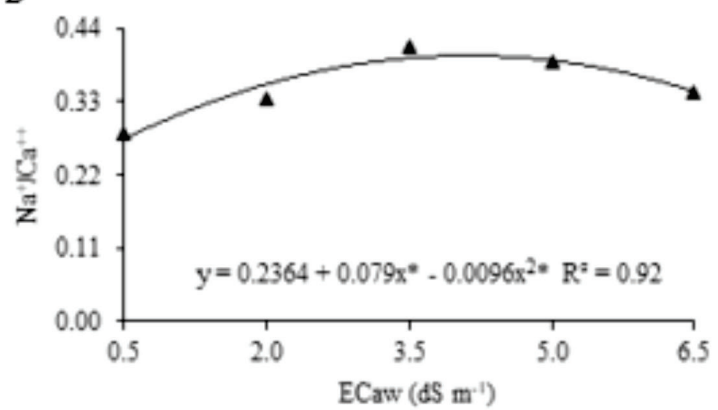

F

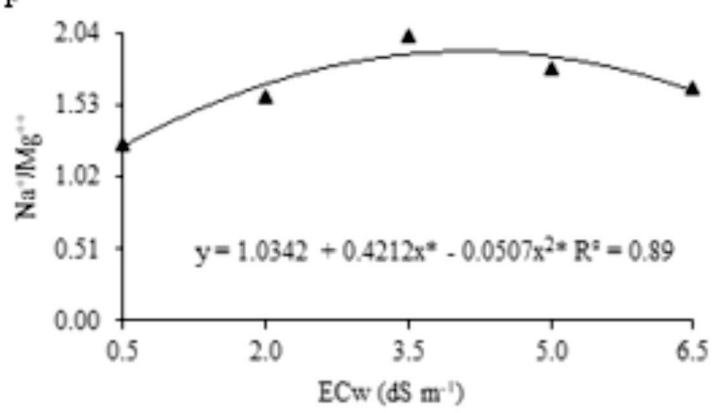

Figure 3. Accumulation of sodium $\left(\mathrm{Na}^{+}\right)(\mathrm{A})$, sodium/potassium ratio $\left(\mathrm{Na}^{+} / \mathrm{K}^{+}\right)(\mathrm{B})$, sodium/calcium ratio $\left(\mathrm{Na}^{+} / \mathrm{Ca}^{++}\right)(\mathrm{C}$ and $\mathrm{D})$ and sodium/ magnesium ratio $\left(\mathrm{Na}^{+} / \mathrm{Mg}^{++}\right)(\mathrm{E}$ and $\mathrm{F})$ in Italian zucchini plants nourished with different forms of nitrogen and irrigated with saline waters. Means followed by different letters indicate significant difference by Tukey test at 0.05 probability level. ${ }^{*}$ and ${ }^{\text {ns }}-$ Significant at 0.05 probability level $(\mathrm{p}<0.05)$ and not significant $(\mathrm{p}>0.05)$, respectively.

A.

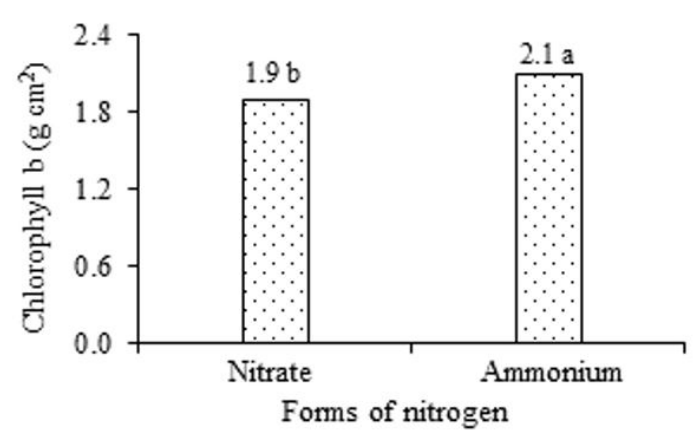

B.

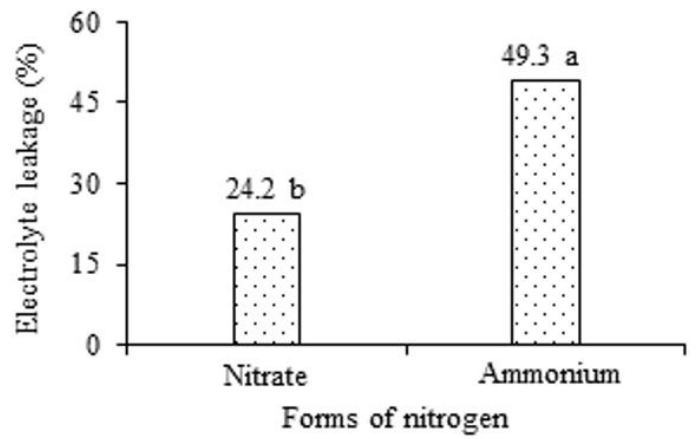

Figure 4. Chlorophyll b content (A) and electrolyte leakage (B) in Italian zucchini plants nourished with different forms of nitrogen and irrigated with saline waters. Means followed by different letters indicate significant difference by Tukey test at 0.05 probability level. 


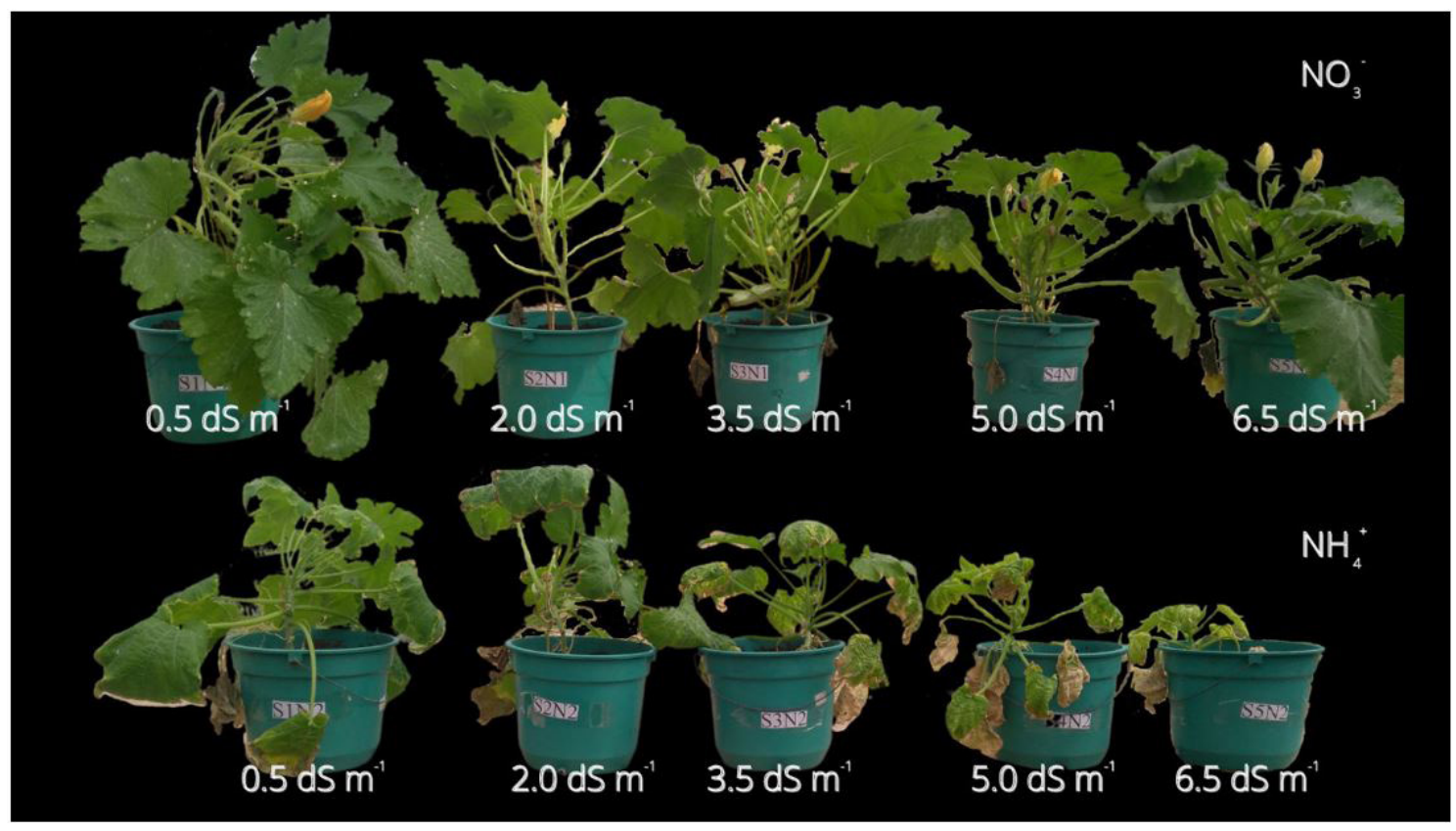

Figure 5. Italian zucchini plants fertilized with different forms of nitrogen and irrigated with saline waters.

A
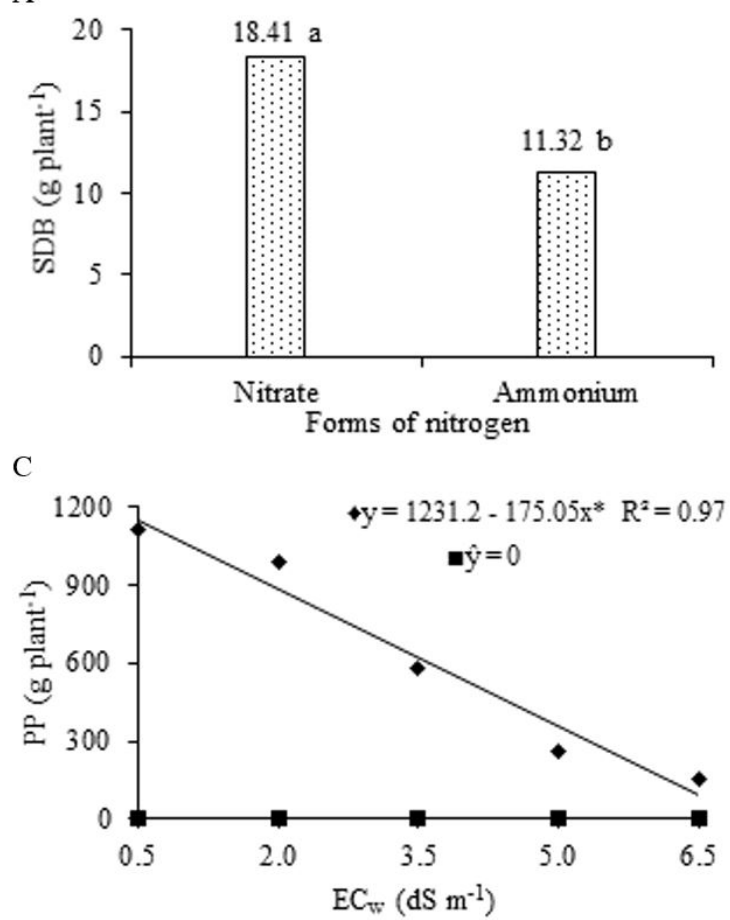

B

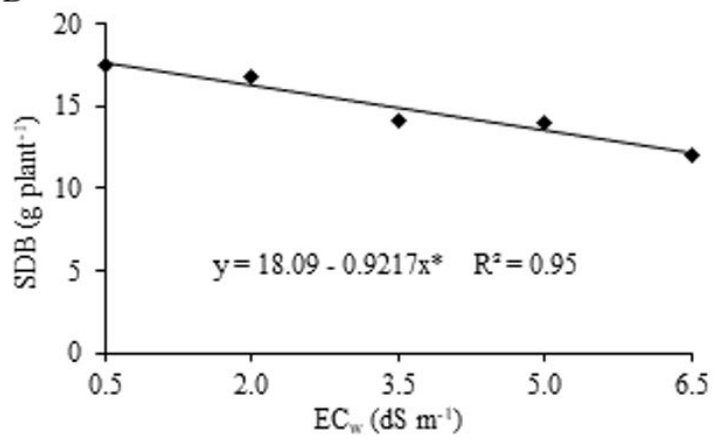

Figure 6. Shoot dry biomass (SDB) (A and B) and production (PP) (C) of Italian zucchini plants fertilized with different forms of nitrogen ( Nitrate and Ammonium) and irrigated with saline waters (B). Means followed by different letters indicate difference by Tukey test at 0.05 probability level. ${ }^{*}=$ Significant at 0.05 probability level $(\mathrm{p}<0.05)$.

plant growth, while the secondary effects are caused by ionic imbalance, resulting in inactivation of enzymes, lack of nutrients, ionic toxicity in tissues and oxidative stress (Nazar et al., 2011). Thus, as observed in the Italian zucchini, salinity affects the establishment, growth, development and production of plants, leading to a significant loss of yield or even death (AcostaMotos et al., 2017).

The reductions in the accumulation of elements such as $\mathrm{N}, \mathrm{K}, \mathrm{Ca}$ and $\mathrm{Mg}$ in plant tissues as a consequence of the 
effects of salinity occur due to the competition between the ions $\mathrm{Cl}^{-}$and $\mathrm{NO}_{3}{ }^{-}$and between the ion $\mathrm{Na}^{+}$and the ions $\mathrm{K}^{+}, \mathrm{Ca}^{++}$and $\mathrm{Mg}^{++}$. Ionic competition causes changes in the availability, absorption, transportation, assimilation and distribution of these elements in the plant, resulting in lower accumulation in its aerial parts, as reported by Carmo et al. (2011); these authors demonstrated that plants of pumpkin irrigated with water of electrical conductivity of $4.38 \mathrm{dS} \mathrm{m}^{-1}$ reduce the accumulation of $\mathrm{N}, \mathrm{P}, \mathrm{K}, \mathrm{Ca}$ and $\mathrm{Mg}$ in their tissues by $30.4 \%, 16.4 \%, 22.5 \%$, $50.5 \%$ and $14.4 \%$, respectively.

Excessive accumulation of elements in plants, especially sodium, inhibits their growth and production due to ionic toxicity, nutritional imbalances or both, simultaneously (Sá et al., 2015). Toxicity causes changes in the ionic ratios $\mathrm{Na}^{+} / \mathrm{K}^{+}, \mathrm{Na}^{+} / \mathrm{Ca}^{++}, \mathrm{Na}^{+} / \mathrm{Mg}^{++}$and $\mathrm{Cl}^{-} / \mathrm{NO}_{3}^{-}$, affecting photophosphorylation, respiratory chain, nutrient assimilation and the metabolism of proteins and other organic compounds, which causes changes in the entire plant metabolism (Viudes and Santos, 2014).

According to Azevedo Neto and Tabosa (2000), determining the ratios of sodium with the macronutrients potassium, calcium and magnesium $\left(\mathrm{Na}^{+} / \mathrm{K}^{+}, \mathrm{Na}^{+} / \mathrm{Ca}^{++}\right.$and $\left.\mathrm{Na}^{+} / \mathrm{Mg}^{++}\right)$is fundamentally important when the aim is to analyze the nutritional status of plants subjected to salt stress, because they indicate their state of nutritional stress. Some authors recommend that ionic ratios should be lower than 0.60 in glycophytes so that there are no losses in their metabolism (Garcia et al., 2007). Based on these criteria, the $\mathrm{Na}^{+} / \mathrm{Mg}^{++}$ratios (Figure $3 \mathrm{~F}$ ) in the Italian zucchini were more than three times higher than that considered appropriate for development.

The reductions in the accumulation of the macronutrients $\mathrm{N}, \mathrm{P}, \mathrm{K}, \mathrm{Ca}$ and $\mathrm{Mg}$ in the shoots of zucchini plants fertilized with $\mathrm{NH}_{4}^{+}$, compared to plants nourished with $\mathrm{NO}_{3}{ }^{-}$, are attributed to the greater reductions caused in the biomass accumulation in these plants when they received this type of fertilization (Figure 6A), since the total amount of macronutrients accumulated in their tissue is directly related to the dry biomass accumulation. These results corroborate those obtained by other authors, which have shown that plants nourished exclusively with nitrogen in the ammoniacal form may have lower contents of elements such as $\mathrm{Ca}^{++}$and $\mathrm{Mg}^{++}$in their tissues, as reported by Borgognone et al. (2013) in tomato plants and by Savvas et al. (2010) in eggplant plants.

In the Italian zucchini, some symptoms of $\mathrm{NH}_{4}^{+}$toxicity were found, such as reduced growth, leaf chlorosis and marginal leaf burns (Figure 5). According to Esteban et al. (2016), these symptoms are due to changes in the ionic balance of plants, since the excess of $\mathrm{NH}_{4}^{+}$inhibits the uptake of other cations, such as $\mathrm{K}^{+}, \mathrm{Mg}^{++}$and $\mathrm{Ca}^{++}$. In addition, excess $\mathrm{NH}_{4}^{+}$also causes, among other things, intracellular alkalinization, extracellular acidification, interference with photosynthetic activity, alteration in the assimilation of enzymes, interruption of hormonal homeostasis and increased oxidative stress (Britto and Kronzucker, 2002; Cruz et al ., 2011; Bittsánszky, et al., 2015; Esteban et al., 2016). This fact is confirmed by the high leakage of electrolytes in the leaves of zucchini.
The reduction in membrane stability occurs due to lipid peroxidation caused by reactive oxygen species (ROS), such as the superoxide radical $\left(\mathrm{O}_{2}^{-}\right)$, singlet oxygen $\left({ }^{1} \mathrm{O}_{2}\right)$, the hydroxyl radical $\left(\mathrm{OH}^{-}\right)$and hydrogen peroxide $\left(\mathrm{H}_{2} \mathrm{O}_{2}\right.$ ) (Singh et al., 2007; Ashraf and Harris, 2004; Sá et al., 2017). As there was no significant effect of ECW on $\mathrm{EE}$, it is deduced that this greater degradation in the membranes of plants fertilized with $\mathrm{NH}_{4}^{+}$happened due to the cytotoxic effects provided by the exclusive absorption of $\mathrm{NH}_{4}^{+}$by the zucchini plants; and the increase in the content of chlorophyll $\mathrm{b}$ in Italian zucchini fertilized with $\mathrm{NH}_{4}{ }^{+}$is indicative that the plant is trying to compensate for the loss caused to the photosynthetic apparatus, with increased synthesis of pigments accessory to light capture (Sá et al., 2017).

Although the ammoniacal fertilization improved ionic homeostasis $\left(\mathrm{Na}^{+} / \mathrm{Ca}^{++}\right.$and $\mathrm{Na}^{+} / \mathrm{Mg}^{++}$), Italian zucchini plants nourished with $\mathrm{NH}_{4}^{+}$were not able to produce fruits. The pollinated flowers were not fertilized and ultimately fell. Possibly, fertilization did not occur because the pollen was non-viable, given that the $\mathrm{NH}_{4}{ }^{+}$ion can promote biochemical and physiological alterations in plants, such as changes in the intracellular $\mathrm{pH}$ and metabolism of hormones (Li et al., 2014). Thus, exclusive fertilization with $\mathrm{NH}_{4}^{+}$is toxic to zucchini plants, with more harmful effects at the flowering stage, so only plants fertilized with $\mathrm{NO}_{3}{ }^{-}$reached the fruiting stage (Figure $6 \mathrm{C}$ ).

In summary, Italian zucchini plants nourished only with ammoniacal nitrogen in the standard nutrient solution promotes greater damage to the leaf membrane and reduced their accumulation of macronutrients and increased their $\mathrm{Na}^{+} / \mathrm{K}^{+}, \mathrm{Na}^{+} / \mathrm{Ca}^{++}$and $\mathrm{Na}^{+} / \mathrm{Mg}^{++}$ratios in the shoots. Irrigation with water above $2.0 \mathrm{dS} \mathrm{m}^{-1}$ reduces the accumulation of nutrients in the shoots and the production of Italian zucchini plants. The toxicity of $\mathrm{NH}_{4}^{+}$ under Italian zucchini plants overlap the toxicity of the salinity, since fertilization with this form of nitrogen inhibits its production, so the $\mathrm{NO}_{3}{ }^{-}$form is the most adequate for its cultivation.

\section{References}

ACOSTA-MOTOS, J., ORTUÑO, M., BERNAL-VICENTE, A., DIAZVIVANCOS, P., SANCHEZ-BLANCO, M. and HERNANDEZ, J., 2017. Plant responses to salt stress: adaptive mechanisms. Agronomy (Basel), vol. 7, no. 18, pp. 1-38. http://dx.doi.org/10.3390/ agronomy7010018.

ASHRAF, M. and HARRIS, P.J.C., 2004. Potential biochemical indicators of salinity tolerance in plants. Plant Science, vol. 166, no. 1, pp. 3-16. http://dx.doi.org/10.1016/j.plantsci.2003.10.024.

AZAMBUJA, L.O., BENETT, C.G.S., BENETT, K.S.S. and COSTA, E., 2015. Produtividade da abobrinha 'Caserta' em função do nitrogênio e gel hidrorretentor. Científica (Jaboticabal), vol. 43, no. 4, pp. 353-358. http://dx.doi.org/10.15361/19845529.2015v43n4p353-358.

AZEVEDO NETO, A.D. and TABOSA, J.N., 2000. Estresse salino em plântulas de milho: parte II distribuição dos macronutrientes catiônicos e suas relações com o sódio. Revista Brasileira de Engenharia Agrícola e Ambiental, vol. 4, no. 2, pp. 165-171. http:// dx.doi.org/10.1590/S1415-43662000000200006. 
BITTSÁNSZKY, A., PILINSZKY, K., GYULAI, G. and KOMIVES, T., 2015 Overcoming ammonium toxicity. Plant Science, vol. 231, no. 2, pp. 184-190. http://dx.doi.org/10.1016/j.plantsci.2014.12.005. PMid:25576003.

BORGOGNONE, D., COLLA, G., ROUPHAEL, Y., CARDARELLI, M., REA E. and SCHWARZ, D., 2013. Effect of nitrogen form and nutrient solution pH on growth and mineral composition of self-grafted and grafted tomatoes. Scientia Horticulturae, vol. 149, no. 4, pp. 61-69. http://dx.doi.org/10.1016/j.scienta.2012.02.012.

BREDEMEIER, C. and MUNDSTOCK, C.M., 2000. Regulação da absorção e assimilação do nitrogênio nas plantas. Ciência Rural, vol. 30, no. 2, pp. 365-372. http://dx.doi.org/10.1590/ S0103-84782000000200029.

BRITTO, D.T. and KRONZUCKER, H.J., 2002. $\mathrm{NH}_{4}^{+}$toxicity in higher plants: a critical review. Journal of Plant Physiology, vol. 159, no. 6, pp. 567-584. http://dx.doi.org/10.1078/0176-1617-0774.

CARMO, G.A., OLIVEIRA, F.R.A., MEDEIROS, J.F., OLIVEIRA, F.A., CAMPOS, M.S. and FREITAS, D.C., 2011. Teores foliares, acúmulo e partição de macronutrientes na cultura da abóbora irrigada com água salina. Revista Brasileira de Engenharia Agrícola e Ambiental, vol. 15, no. 5, pp. 512-518. http://dx.doi.org/10.1590/ S1415-43662011000500012.

CHAVES, L.H.G., GHEYI, H.R. and RIBEIRO, S., 2011. Consumo de água e eficiência do uso para cultivar de mamona Paraguaçu submetida à fertilização nitrogenada. Engenharia Ambiental, vol. 8, no. 1, pp. 126-133.

CRUZ, C., DOMÍNGUEZ-VALDIVIA, M.D., APARICIO-TEJO, P.M., LAMSFUS, C., BIO, A., MARTINS-LOUÇÃO, M.A. and MORAN, J.F., 2011. Intra-specific variation in pea responses to ammonium nutrition leads to different degrees of tolerance. Environmental and Experimental Botany, vol. 70, no. 2-3, pp. 233-243. http:// dx.doi.org/10.1016/j.envexpbot.2010.09.014.

DIAS, N.S., BLANCO, F.F., SOUZA, E.R., FERREIRA, J.F.S., SOUSA NETO, O.N. and QUEIROZ, I.S.R., 2016. Efeitos dos sais na planta e tolerância das culturas à salinidade. In: H.R. GHEYI, N.S. DIAS, C.F. LACERDA and E. GOMES FILHO, org. Manejo da salinidade na agricultura: Estudos básicos e aplicados. 2nd ed. Fortaleza: INCTsal, Cap. 11, pp. 151-161.

DINIZ, M.T.M. and PEREIRA, V.H.C., 2015. Climatologia do estado do Rio Grande do Norte, Brasil: sistemas atmosféricos atuantes e mapeamento de tipos de clima. Boletim Goiano de Geografia, vol. 35, no. 3, pp. 488-506.

EMPRESA BRASILEIRA DE PESQUISA AGROPECUÁRIA - EMBRAPA, 2009. Manual de análises químicas de solos, plantas e fertilizantes. 2nd ed. Brasília: Embrapa Informação Tecnológica. 627 p.

ESTEBAN, R., ARIZ, I., CRUZ, C. and MORAN, J.F., 2016. Review: mechanisms of ammonium toxicity and the quest for tolerance. Plant Science, vol. 248, no. 7, pp. 92-101. http://dx.doi. org/10.1016/j.plantsci.2016.04.008. PMid:27181951.

FERNÁNDEZ-CRESPO, E., CAMANES, G. and GARCÍA-AGUSTÍN, P., 2012. Ammonium enhances resistance to salinity stress in citrus plants. Journal of Plant Physiology, vol. 169, no. 12, pp. 1183-1191. http://dx.doi.org/10.1016/j.jplph.2012.04.011. PMid:22721954.

FURLANI, P.R., BOLONHEZI, D., SILVEIRA, L.C.P., and FAQUIN, V., 1999. Nutrição mineral de hortaliças, preparo e manejo de soluções nutritivas. Informe Agropecuário, vol. 20, no. 200201, pp. 90-98.

GARCIA, G.O., FERREIRA, P.A., MIRANDA, G.V., NEVES, J.C.L., MORAES, W.B. and SANTOS, D.B., 2007. Teores foliares dos macronutrientes catiônicos e suas relações com sódio em plantas de milho sob estresse salino. Idesia, vol. 25, no. 3, pp. 93-106. http://dx.doi. org/10.4067/S0718-34292007000300010.
HELALI, S.M., NEBLI, H., KADDOUR, R., MAHMOUDI, H., LACHAÂL, M. and OUERGHI, Z., 2010. Influence of nitrate-ammonium ratio on growth and nutrition of Arabidopsis thaliana. Plant and Soil, vol. 336, no. 1-2, pp. 65-74. http://dx.doi.org/10.1007/ s11104-010-0445-8.

HESSINI, K., HAMED, K.B., GANDOUR, M., MEJRI, M., ABDELLY, C. and CRUZ, C., 2013. Ammonium nutrition in the halophyte Spartina alterniflora under salt stress: evidence for a priming effect of ammonium? Plant and Soil, vol. 370, no. 1-2, pp. 163173. http://dx.doi.org/10.1007/s11104-013-1616-1.

LI, B., LI, G., KRONZUCKER, H.J., BALUŠKA, F. and SHI, W., 2014. Ammonium stress in Arabidopsis: Signaling, genetic loci, and physiological targets. Trends in Plant Science, vol. 19, no. 2, pp. 107-114. http://dx.doi.org/10.1016/j.tplants.2013.09.004. PMid:24126103.

MCALLISTER, C.H., BEATTY, P.H. and GOOD, A.G., 2012. Engineering nitrogen use efficient crop plants: the current status. Plant Biotechnology Journal, vol. 10, no. 9, pp. 1011-1025. http:// dx.doi.org/10.1111/j.1467-7652.2012.00700.x. PMid:22607381.

MEDEIROS, J.C.C., COELHO, F.F. and TEIXEIRA, E., 2016. Biomass allocation and nutrients balance related to the concentration of nitrogen and phosphorus in Salvinia auriculata (Salviniaceae). Brazilian Journal of Biology = Revista Brasileira de Biologia, vol. 76, no. 2, pp. 461-468. http://dx.doi.org/10.1590/1519-6984.21114. PMid:26959946.

MIRANDA, R.D.S., GOMES-FILHO, E., PRISCO, J.T. and ALVAREZPIZARRO, J.C., 2015. Ammonium improves tolerance to salinity stress in Sorghum bicolor plants. Plant Growth Regulation, vol. 78, no. 1, pp. 121-131. http://dx.doi.org/10.1007/s10725-015-0079-1.

NAZAR, R., IQBAL, N., SYEED, S. and KHAN, N.A., 2011. Salicylic acid alleviates decreases in photosynthesis under salt stress by enhancing nitrogen and sulfur assimilation and antioxidant metabolism differentially in two mungbean cultivars. Journal of Plant Physiology, vol. 168, no. 8, pp. 807-815. http://dx.doi. org/10.1016/j.jplph.2010.11.001. PMid:21112120.

OLIVEIRA, F.A., OLIVEIRA, F.R.A., CAMPOS, M.S., OLIVEIRA, M.K.T., MEDEIROS, J.F. and SILVA, O.M.P., 2010. Interação entre salinidade e fontes de nitrogênio no desenvolvimento inicial da cultura do girassol. Agrária, vol. 5, no. 4, pp. 479-484. http://dx.doi. org/10.5039/agraria.v5i4a806.

SÁ, F.V.S., BRITO, M.E.B., FIGUEIREDO, L.C., MELO, A.S., SILVA, L.A. and MOREIRA, R.C.L., 2017. Biochemical components and dry matter of lemon and mandarin hybrids under salt stress. Revista Brasileira de Engenharia Agrícola e Ambiental, vol. 21, no. 4, pp. 249-253. http://dx.doi.org/10.1590/1807-1929/agriambi. v21n4p249-253.

SÁ, F.V.S., BRITO, M.E.B., SILVA, L.A., MOREIRA, R.C.L., FERNANDES, P.D. and FIGUEIREDO, L.C., 2015. Fisiologia da percepção do estresse salino em híbridos de tangerineira - Sunki Comum sob solução hidropônica salinizada. Comunicata Scientiae, vol. 6, no. 4, pp. 463-470. http://dx.doi.org/10.14295/cs.v6i4.1121.

SAVVAS, D., LENETI, H., MANTZOS, N., KAKARANTZA, L. and BAROUCHAS, P., 2010. Effects of enhanced $\mathrm{NH}_{4}^{+}-\mathrm{N}$ supply and concomitant changes in the concentrations of other nutrients needed for ion balance on the growth, yield, and nutrient status of eggplants grown on rockwool. The Journal of Horticultural Science E Biotechnology, vol. 85, no. 4, pp. 355-361. http:// dx.doi.org/10.1080/14620316.2010.11512680.

SINGH, H.P., BATISH, D.R., KOHLI, R.K. and ARORA, K., 2007. Arsenicinduced root growth inhibition in mung bean (Phaseolus aureus Roxb.) is due to oxidative stress resulting from enhanced lipid peroxidation. Plant Growth Regulation, vol. 53, no. 7, pp. 65-73. http://dx.doi.org/10.1007/s10725-007-9205-z. 
SILVA JÚNIOR, G.B., PRADO, R.M., CAMPOS, C.N.S., AGOSTINHO, F.B., SILVA, S.L.O., SANTOS, L.C.N. and GONZÁLEZ, L.C., 2019. Silicon mitigates ammonium toxicity in yellow passionfruit seedlings. Chilean Journal of Agricultural Research, vol. 79, no. 3, pp. 425434. http://dx.doi.org/10.4067/S0718-58392019000300425.

TEDESCO, M.J., GIANELLO, C., BISSANI, C.A., BOHNEN, H. and VOLKWEISS, S.J., 1995. Análise de solo, plantas e outros materiais. 2. ed. Porto Alegre: Departamento de Solos, Universidade Federal do Rio Grande do Sul, 174 p. Boletim Técnico de Solos, 5.
VIUDES, E.B. and SANTOS, A.C.P., 2014. Caracterização fisiológica e bioquímica de artemisia (Artemisia annua L.) submetida a estresse salino. Colloquium Agrariae, vol. 10, no. 2, pp. 84-91. http://dx.doi.org/10.5747/ca.2014.v10.n2.a111.

WELLBURN, A.R., 1994. The spectral determination of chlorophyll a and $b$, as well as total carotenoids, using various solvents with spectrophotometers of different resolution. Journal of Plant Physiology, vol. 144, no. 3, pp. 307-313. http://dx.doi. org/10.1016/S0176-1617(11)81192-2. 